\title{
Modeling and Analysis of an Integrated Power System Based on Methanol Autothermal Reforming
}

\author{
Dimitris Ipsakis $^{1,2}$, Spyros Voutetakis ${ }^{1}$, Panos Seferlis $^{3}$, Simira Papadopoulou ${ }^{1,4}$, Michael Stoukides ${ }^{2}$
}

\author{
${ }^{1}$ Chemical Process Engineering Research Institute \\ (C.P.E.R.I.), CEntre for Research and Technology Hellas \\ (CE.R.T.H.), P.O. Box 60361, 57001 Thermi-Thessaloniki, \\ Greece (Tel: +30-2310-498 317; email:paris@cperi.certh.gr). \\ ${ }^{2}$ Department of Chemical Engineering, Aristotle University \\ of Thessaloniki, P.O. Box 1517, 54124 Thessaloniki, Greece \\ (Tel: +30-2310-498 353; email:ipsakis@cperi.certh.gr).
}

\begin{abstract}
The integrated power system under consideration, consists of the fuel processor (reformer and preferential oxidation reactors), the fuel cell and the heat management system. In the reformer reactor, methanol, air and water are co-fed to produce hydrogen under autothermal conditions. The produced hydrogen due to the high content of $\mathrm{CO}(>5000 \mathrm{ppm})$, is treated in the preferential oxidation reactor (PROX) for the CO minimization at acceptable levels $(<50 \mathrm{ppm})$. After the oxidation clean-up step, the anode of the polymer electrolyte membrane (PEM) fuel cell is fed with the reformate gas ( $\sim 60$ $65 \% \mathrm{H}_{2}, \sim 15-25 \% \mathrm{CO}_{2}, \sim 15-20 \% \mathrm{~N}_{2}, \sim 1-3 \% \mathrm{CH}_{3} \mathrm{OH}$ and traces of $\mathrm{CO}$ ). The present paper is focused on the mathematical analysis of the main subsystems of the integrated power unit. The two reactors are modeled via a system of partial differential equations (PDE's) and the species flowrates and reactor temperature are analyzed along the length of each reactor. Moreover, the PEM fuel cell voltage-current characteristic is modeled via a non-linear equation that depends on the mass $\&$ energy balances (ordinary differential equations) of the concerned species. Finally, the heat management system is analyzed in order to provide insights for future control studies that will depend on the developed mathematical model (model-based control).
\end{abstract}

Keywords: integrated systems; dynamic modeling; methanol reforming; preferential oxidation; PEM fuel cell; hydrogen;

\section{INTRODUCTION}

Alternative methods for cleaner energy production require the exploitation of renewable and alternative energy sources. Solar and wind energy exploitation is of usual interest in stand-alone applications [1], but for portable and transportation usages, biomass resources are used. A characteristic of alternative integrated power systems is the use of hydrogen as an intermediatte energy source. Hydrogen is used for power generation in fuel cells and its production is usually fulfilled by hydrocarbons reforming, such as methanol [2]. Methanol advantages include the flexible storage abilities, the presence of high $\mathrm{H}: \mathrm{C}$ ratio and no $\mathrm{C}: \mathrm{C}$ ratio and also the absence of high reforming temperatures and sulphur oxides that are usually met in natural gas and

\author{
${ }^{3}$ Department of Mechanical Engineering, Aristotle \\ University of Thessaloniki, P.O. Box 484, \\ 54124 Thessaloniki, Greece (Tel: +30-2310-994 229; \\ email:seferlis@cperi.certh.gr). \\ ${ }^{4}$ Department of Automation, Alexander Technological \\ Educational Institute of Thessaloniki, P.O. Box 1456, \\ 54101 Thessaloniki, Greece (Tel: +30-2310-498 319; \\ email:shmira@teithe.gr).
}

gasoline reforming. Steam reforming, partial oxidation and autothermal reforming, are the three main processes for producing hydrogen from methanol [3]. Steam reforming leads to a high level of hydrogen at the outlet stream $(\sim 75 \%)$, but is a reaction that is endothermic and requires heat to be provided by an external source (e.g. burner). Partial oxidation eliminates the use of a burner, but the high temperatures lead to the formation of hot spots in the catalyst, while the produced hydrogen remains at low levels $(\sim 45 \%)$. In the autothermal steam reforming, oxygen, water and methanol are co-fed to the reformer and the reactants ratios are chosen in such a way, so that a slightly exothermic or thermally neutral reaction scheme can be achieved [4]. Hence, autothermal reforming eliminates the disadvantages of the above procedures and is considered the most effective method for hydrogen production at an autonomous power unit that uses methanol. On the other hand, hydrocarbons reforming cause the production of $\mathrm{CO}$ at levels that poison the anode of PEM fuel cells. Among all processes reported for the minimization of $\mathrm{CO}$ content, preferential oxidation is considered to be the simplest and the least expensive method [5].

Review in literature reveals a scarce number of studies dealing with integrated systems. Most studies focus on each subsystem and PROX reactors have been modelled using 2D steady-state models [6], while steam reformers have also been modelled using axial distribution models [7]. In one of the very few papers on integrated systems, Stamps A. T. and Gatzke E.P. [8], developed and implemented a system level model of a vehicular reformer-PEM fuel cell stack power system without focusing on the system dynamic interactions. Hence, the main target of this research work is to present a complete study of an integrated system under operation. Aim is the effective integration of the developed mathematical models of the subsystems. Based on them the system dynamic results will be presented and discussed for simple case scenarios applied. Moreover, an analysis on the heat management system will be given in order to provide insights for future control studies. 


\section{ANALYSIS OF THE INTEGRATED POWER SYSTEM}

Fig. 1, shows the process flow diagram of the methanol autothermal reforming unit.

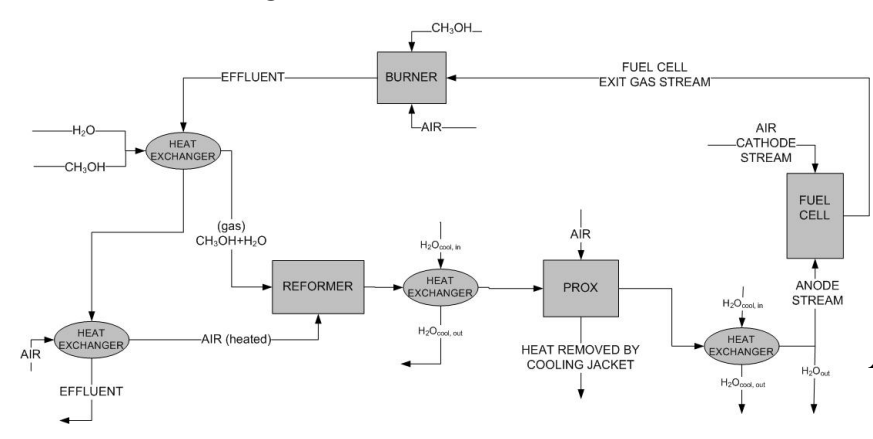

Figure 1. Simplified process flow diagram of the methanol autothermal reforming unit.

Methanol and water are evaporated and preheated with the use of a burner before their introduction to the reformer $(0.15 \mathrm{~m}$ length and $0.1 \mathrm{~m}$ diameter $)$. At the same time, air is preheated and also introduced to the reformer to provide the necessary heat to the system. The ratios of the reactants are chosen in such a way, so that the overall process in the reformer is considered adiabatic. From Aspen Plus ${ }^{\mathbb{B}}$ simulations it was found that the optimum values for $\mathrm{H}_{2} \mathrm{O} / \mathrm{CH}_{3} \mathrm{OH}$ and $\mathrm{O}_{2} / \mathrm{CH}_{3} \mathrm{OH}$ are between 1.5-1.7 and 0.10.15 respectively, unless stated otherwise. The reactions that take place at the reformer are:

Steam Reforming

$\mathrm{CH}_{3} \mathrm{OH}+\mathrm{H}_{2} \mathrm{O} \rightarrow \mathrm{CO}_{2}+3 \mathrm{H}_{2} \quad \Delta \mathrm{H}_{\mathrm{R}, 298}=49 \mathrm{~kJ} / \mathrm{mol}$

Partial Oxidation

$\mathrm{CH}_{3} \mathrm{OH}+0.5 \mathrm{O}_{2} \rightarrow \mathrm{CO}_{2}+2 \mathrm{H}_{2} \quad \Delta \mathrm{H}_{\mathrm{R}, 298}=-193 \mathrm{~kJ} / \mathrm{mol}$

Water Gas Shift

$\mathrm{CO}+\mathrm{H}_{2} \mathrm{O} \leftrightarrow \mathrm{CO}_{2}+\mathrm{H}_{2}$

$\Delta \mathrm{H}_{\mathrm{R}, 298}=-41.2 \mathrm{~kJ} / \mathrm{mol}$

Methanol Decomposition

$\mathrm{CH}_{3} \mathrm{OH} \rightarrow \mathrm{CO}+2 \mathrm{H}_{2}$

$\Delta \mathrm{H}_{\mathrm{R}, 298}=90.1 \mathrm{~kJ} / \mathrm{mol}$

Since $\mathrm{CO}$ production takes place at the reformer, its minimization is required. At the PROX reactor $(0.1 \mathrm{~m}$ length and $0.1 \mathrm{~m}$ diameter), $\mathrm{CO}$ and $\mathrm{H}_{2}$ oxidation take place:

Carbon Monoxide Oxidation

$$
\begin{array}{lc}
\mathrm{CO}+0.5 \mathrm{O}_{2} \rightarrow \mathrm{CO}_{2} & \Delta \mathrm{H}_{\mathrm{R}, 298}=-283 \mathrm{~kJ} / \mathrm{mol} \\
\underline{\text { Hydrogen Oxidation }} & \\
\mathrm{H}_{2}+0.5 \mathrm{O}_{2} \rightarrow \mathrm{H}_{2} \mathrm{O} & \Delta \mathrm{H}_{\mathrm{R}, 298}=-242 \mathrm{~kJ} / \mathrm{mol}
\end{array}
$$

The main objective of the PROX reactor is to keep the $\mathrm{CO}$ concentration at a maximum limit of $50 \mathrm{ppm}$ by using efficiently the $\mathrm{O}_{2} / \mathrm{CO}$ ratio. From Aspen Plus ${ }^{B(1)}$ simulations, its value for the current study is higher than 1 for a $\mathrm{CO}$ conversion $>95 \%$, but could vary severely with the inlet CO concentration. For all the aforementioned reactions, kinetic expressions of the Arrhenius type are selected and their main form is presented in [2].
In the final step, the hydrogen rich-stream is fed to the anode of the PEM fuel cell, where protons $\left(\mathrm{H}^{+}\right)$and electrons $\left(\mathrm{e}^{-}\right)$are released and react with oxygen (fed via air supply) at the cathode to form water [9]:

$$
\begin{aligned}
& \text { Anode } \\
& \mathrm{H}_{2} \rightarrow 2 \mathrm{H}^{+}+2 \mathrm{e}^{-} \\
& \frac{\text { Cathode }}{0.5 \mathrm{O}_{2}+2 \mathrm{H}^{+}+2 \mathrm{e}^{-} \rightarrow \mathrm{H}_{2} \mathrm{O}}
\end{aligned}
$$

\section{MATHEMATICAL DESCRIPTION OF THE SUBSYSTEMS}

\section{A. Reformer and PROX reactors}

The model equations for the two catalytic reactors consist of the standard material and energy balances for a packedbed type reactor and are in partial differential form. In order to simplify the model and reduce the computational effort needed to simulate all the subsystems, a number of assumptions is employed: 1) The ideal gas law is applied for all gas components, 2) no diffusion phenomena are assumed to take place from the gas phase to the surface of the catalyst 3) constant reactor pressure (no system pressure drop) and fluid velocity, 4) constant physical properties over the range of conditions in the system and 5) the temperature in the cooling jacket of the PROX reactor is aprroximately uniform and the resistance to heat transfer occurs primarily between the reactor contents and the wall of the tube (being at the cooling medium temperature). With the above assumptions, the tubular reactors can be adequately described by a pseudohomogeneous, two dimensional mathematical model.

\section{Material Balance Equation}

$$
\begin{aligned}
& \frac{\partial \mathrm{C}_{\mathrm{i}}}{\partial \mathrm{t}}+\mathrm{u} \cdot \frac{\partial \mathrm{C}_{\mathrm{i}}}{\partial \mathrm{z}}-\varepsilon_{\text {cat }} \cdot D_{z} \frac{\partial^{2} C_{i}}{\partial z^{2}} \\
& -\varepsilon_{\text {cat }} \cdot D_{r} \cdot\left(\frac{\partial^{2} C_{i}}{\partial r^{2}}+\frac{1}{r} \cdot \frac{\partial C_{i}}{\partial r}\right)=\sum_{i=1}^{N} \sum_{j=1}^{R} v_{i, j} \cdot R_{j}
\end{aligned}
$$

\section{Energy Balance Equation}

$$
\begin{aligned}
& \sum_{\mathrm{i}=1}^{\mathrm{N}} \rho_{\mathrm{i}} \cdot \mathrm{C}_{\mathrm{p}, \mathrm{i}} \cdot \frac{\partial \mathrm{T}}{\partial \mathrm{t}}+\sum_{\mathrm{i}=1}^{\mathrm{N}} \rho_{\mathrm{i}} \cdot \mathrm{C}_{\mathrm{p}, \mathrm{i}} \mathrm{u} \cdot \frac{\partial \mathrm{T}}{\partial \mathrm{z}} \\
& -k_{z} \frac{\partial^{2} T}{\partial z^{2}}-k_{r}\left(\frac{\partial^{2} T}{\partial r^{2}}+\frac{1}{r} \cdot \frac{\partial T}{\partial r}\right)=-\sum_{\mathrm{j}=1}^{\mathrm{R}} \mathrm{R}_{\mathrm{j}} \cdot\left(\Delta \mathrm{H}_{R, T, j}\right)
\end{aligned}
$$

\section{Coolant Energy Balance Equation}

$$
\begin{aligned}
& \rho_{c} \cdot V_{c} \cdot C p_{c} \cdot \frac{\partial \mathrm{T}_{\mathrm{c}}}{\partial \mathrm{t}}=F_{c} \cdot C p_{c} \cdot\left(T_{c, \text { in }}-T_{c}\right)+Q \\
& Q=U \cdot A \int_{o}^{\text {Re } \text { actorLength }}\left(T-T_{c}\right) \cdot d z
\end{aligned}
$$

\section{Ideal Gas Law}

$$
P_{i}=C_{i} \cdot R \cdot T
$$




\section{Species Flowrate}

$$
\begin{aligned}
& Q_{o}=u \cdot S=\frac{\sum F_{i, \text { in }} \cdot R \cdot T_{i n}}{P_{\text {reactor }}} \\
& F_{i}=C_{i} \cdot Q_{o}
\end{aligned}
$$

\section{Boundary Conditions (Eqs. 1-4)}

$$
\begin{aligned}
& z=0 \\
& \mathrm{C}_{\mathrm{i}}=\mathrm{C}_{\mathrm{i}, \text { in }} \text { and } \mathrm{T}=\mathrm{T}_{\text {in }}, \quad \mathrm{r} \varepsilon[0, \mathrm{R}] \\
& z=L \\
& \frac{\partial \mathrm{C}_{\mathrm{i}}}{\partial \mathrm{z}}=0 \text { and } \frac{\partial \mathrm{T}}{\partial \mathrm{z}}=0, \quad \mathrm{r} \varepsilon[0, \mathrm{R}] \\
& r=0 \\
& \frac{\partial \mathrm{C}_{\mathrm{i}}}{\partial \mathrm{r}}=0 \text { and } \frac{\partial \mathrm{T}}{\partial \mathrm{r}}=0, \quad \mathrm{z} \varepsilon(0, \mathrm{~L}) \\
& r=R \\
& \frac{\partial \mathrm{C}_{\mathrm{i}}}{\partial \mathrm{r}}=0 \text { and }-k_{r} \cdot \frac{\partial \mathrm{T}}{\partial \mathrm{r}}=h_{w} \cdot\left(T-T_{c}\right), \mathrm{z} \varepsilon(0, \mathrm{~L})
\end{aligned}
$$

In the solution of the reformer, $\mathrm{h}_{\mathrm{w}}$ is 0 and for the PROX $\neq 0$. For the discretization of the distributions, the method of centered finite difference ( $2^{\text {nd }}$ order) was used. The discretization of the axial and radial distribution was performed for 50 and 5 intervals, respectively.

\section{B. PEM Fuel Cell}

The ideal fuel cell voltage is equal to the thermodynamic potential, divided by the flow of the charge for the two electrons that are released [9]:

$$
\mathrm{E}=\frac{-\Delta \mathrm{G}_{\mathrm{f}}}{\mathrm{n}_{\mathrm{e}} \cdot \mathrm{F}}
$$

However, the actual voltage is less due to activation losses $\left(\mathrm{V}_{\text {act }}\right)$, ohmic losses $\left(\mathrm{V}_{\text {ohmic }}\right)$ and concentration losses $\left(\mathrm{V}_{\mathrm{mtl}}\right)[9,10]$ :

$$
V_{f c}=\mathrm{E}-\mathrm{V}_{\text {act }}-V_{\text {ohmic }}-V_{\text {mtt }} \quad .
$$

$\mathrm{V}_{\text {act }}, \mathrm{V}_{\text {ohmic }}$ and $\mathrm{V}_{\mathrm{mtl}}$ losses, depend on the partial pressures of the reactants and on the fuel cell temperature [9, 10]. The mass balance at the anode and cathode is given by Eq.(22):

$$
\frac{d\left(\mathrm{~V}_{\mathrm{an} / \mathrm{at}} \cdot \mathrm{C}_{i}\right)}{d \mathrm{t}}=Q_{a n / c a t} \cdot\left(C_{i, i n}-C_{i}\right)-\frac{\mathrm{n}_{\mathrm{c}} \cdot \mathrm{I}}{\mathrm{n}_{\mathrm{e}} \cdot \mathrm{F}} \cdot n_{\mathrm{F}}
$$

The last part of the equation is positive when water production is considered and negative for hydrogen and oxygen consumption. The thermal model describing the fuel cell temperature is [10]:

$$
C_{t} \cdot \frac{d \mathrm{~T}_{\mathrm{fc}}}{d \mathrm{t}}=n_{c} \cdot I^{2} \cdot\left(R_{a}+R_{\mathrm{int}}\right)-\frac{\left(T_{f c}-T_{a m b}\right)}{R_{t}} \cdot
$$

$R_{a}$ and $R_{\text {int }}$ are reristances that are related to activation and ohmic losses respectively, and are given by non-linear equations [10].

Based on the experimental results presented in [2], validation with the above mathematical model has been performed both for the reformer and PROX. Figures 2 and 3 show the comparison between the experimental data and mathematical model for the two reactors, respectively. The deviation between simulated and experimental values is within the experimental error (less than 5\%) and only in low PROX temperatures a higher deviation is detected but considered negligible, since PROX operates in temperatures $>150^{\circ} \mathrm{C}[2]$.

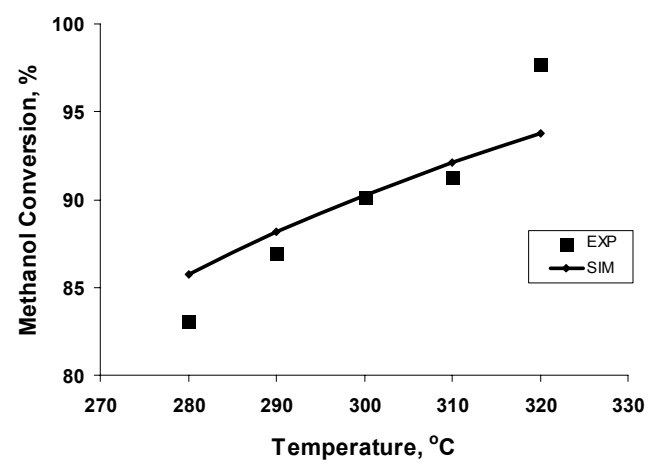

Figure 2. Comparison between simulated and experimental results for the reformer

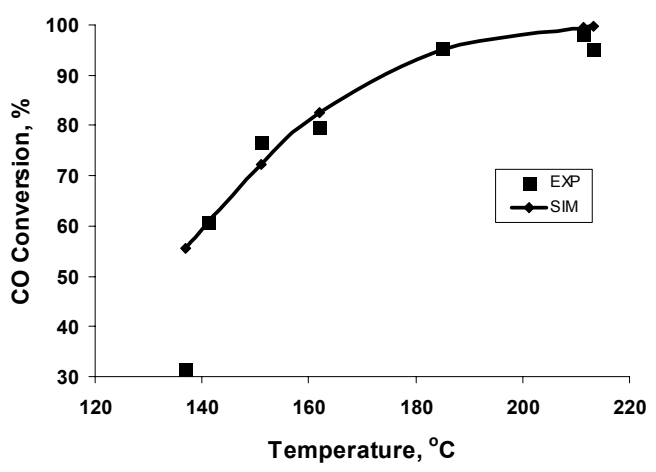

Figure 3. Comparison between simulated and experimental results for the PROX

\section{DYNAMIC RESULTS FROM THE OPERATION OF THE INTEGRATED POWER SYSTEM}

For the presented case study, the reformer operates at $300^{\circ} \mathrm{C}$ and the selected ratios are $\mathrm{H}_{2} \mathrm{O} / \mathrm{CH}_{3} \mathrm{OH}: 1.5$ and $\mathrm{O}_{2} / \mathrm{CH}_{3} \mathrm{OH}: 0.14$. Moreover the PROX temperature is $200^{\circ} \mathrm{C}$ and the $\mathrm{O}_{2} / \mathrm{CO}$ is 2 . The flowrates of the reactants and the 
temperature at the inlet of the reformer do not have a sharp constant value at the start of the simulation time, but a value that increases smoothly with time and reaches its steady state value after a few seconds. Fig. 4 shows the methanol flowrate consumption along the reactor length where at the end of the reformer, methanol conversion reaches approximately $99 \%$. An interesting result is that methanol is consumed very fast at the short lengths $(<0.05 \mathrm{~m})$ of the reformer and more slowly through the rest of reactor.

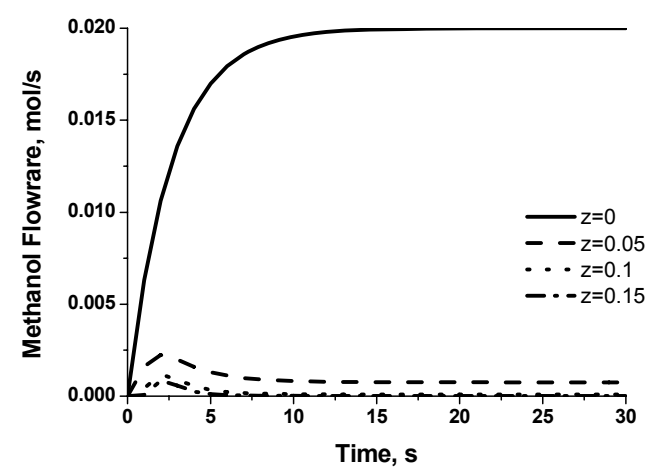

Figure 4. Methanol flowrate as a function of time and reformer length.

Similarly, hydrogen and carbon dioxide flowrates (Fig. 5 ), increase with time and along the length reactor due to the consumption of methanol and reach their steady value after $\sim 15 \mathrm{~s}$.

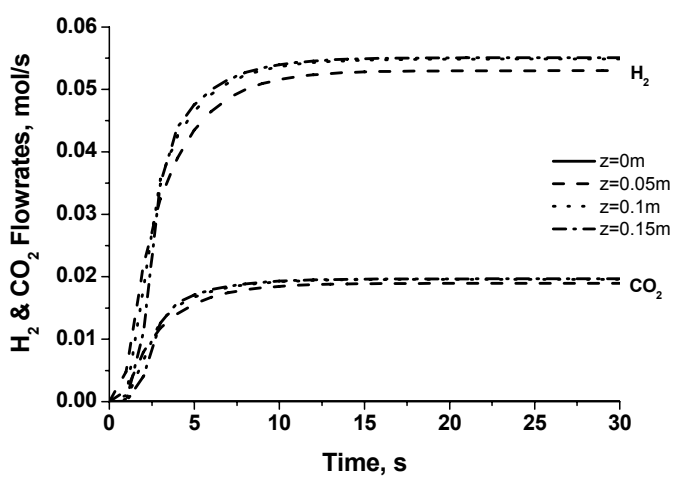

Figure 5. Hydrogen and carbon dioxide flowrates as a function of time and reformer length

Fig. 6 shows that $\mathrm{CO}$ content increases rapidly at the short lengths of the reformer and through the rest of the reactor its increase is considered to take place more slowly. The reason behind this behavior is that most of the methanol has been consumed and $\mathrm{CO}$ has nearly reached equilibrium conditions.

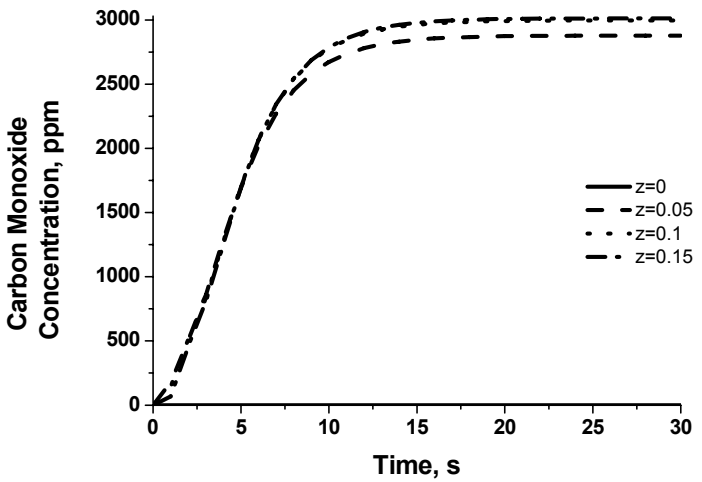

Figure 6. Carbon monoxide concentration as a function of time and reformer length

Finally, Fig. 7 presents the temperature profile in the reformer, where it can be seen that initially the temperature in the various positions in the reactor is decreased because low temperature gas mixture passes, but after $\sim 3 \mathrm{~s}$, the temperature is moved to higher levels. In general, it can be said that the endothermic reactions prevail and the temperature is moved to lower levels, while the smooth increase of temperature at the inlet of the reactor inhibits the hot spots that are usually detected at the short lengths of the reformer due to the exothermic reaction of partial oxidation.

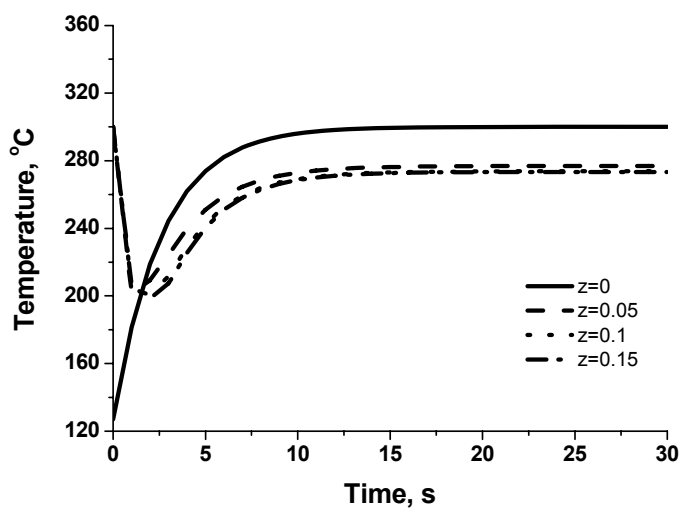

Figure 7. Temperature as a function of time and reformer length.

The inlet flowrates of the PROX are equal to the outlet flowrates of the reformer, but the reformer exit is assumed to be cooled to the PROX operation temperature. However, the dynamics of heat exchangers are omitted for this study. Fig. 8 shows the carbon monoxide concentration along the PROX length. As can be seen, carbon monoxide decreases along the length of PROX with time and eventually at the end of PROX, carbon monoxide levels are at acceptable levels for use in PEM fuel cells. Special caution however should be given to the $\mathrm{O}_{2} / \mathrm{CO}$ ratio that mainly affects the $\mathrm{CO}$ conversion. Based on the $\mathrm{CO}$ content at the reformer exit, the air feed rate at the PROX is manipulated accordingly in order to always have a constant value at the ratio of $\mathrm{O}_{2} / \mathrm{CO}$ (an equivalent of a feedforward control scheme). 


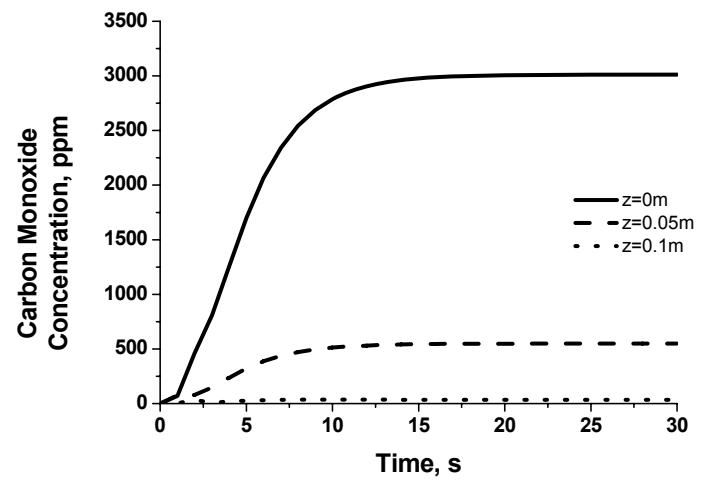

Figure 8. Carbon monoxide concentration as a function of time and PROX length.

The temperature profile of PROX is presented in Fig.9. The highly exothermic reactions cause the sharp increase inside the reactor and thus, making the control system essential in controlling the temperature at acceptable levels. Eventually, temperature is moved to lower temperatures due to the coolant effect. It is highlighted that the temperature levels presented refer to an average value in the radial domain calculated by Eq.10. At the wall of the tube the temperature is lower than $200^{\circ} \mathrm{C}$ which mainly results in the initial temperature decrease.

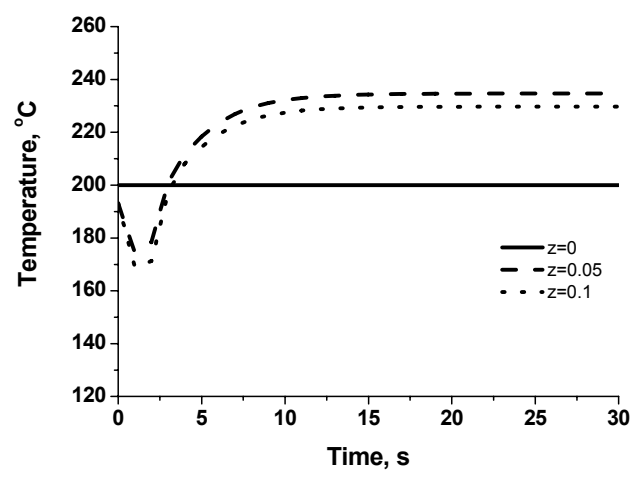

Figure 9. Temperature as a function of time and PROX length.

Fig. 10, shows the voltage-time description of the PEM fuel cell.

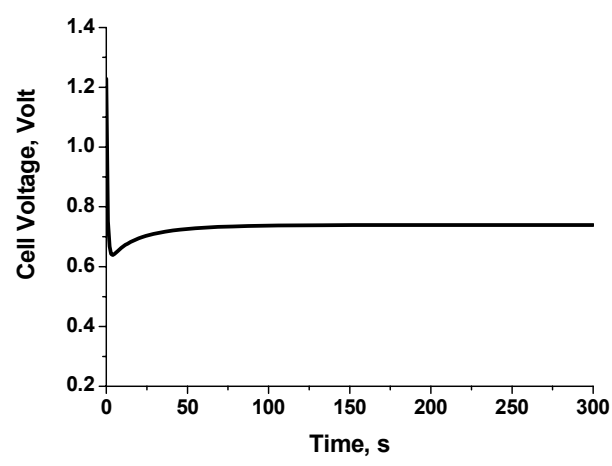

Figure 10. Cell voltage as a function of time.
The operation current is set at 100 which is assumed to reach its steady-state value rapidly $(<10 \mathrm{sec})$. At the start of the simulation time, the voltage decreases due to the sharp increase of the operation current $(<10 \mathrm{sec})$, but as the temperature increases (Fig. 11), the voltage increase is favored and reaches its steady-state value after about $300 \mathrm{sec}$.

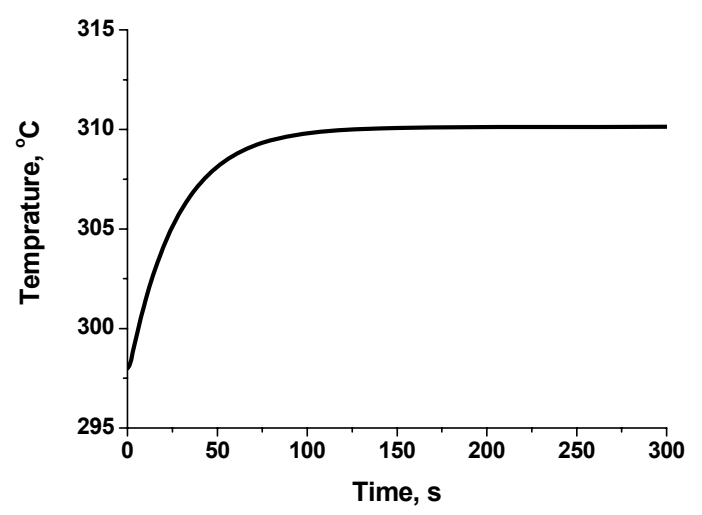

Figure 11. Fuel cell stack temperature as a function of time.

\section{A. Case Scenarios}

Table I presents the effect of the $\mathrm{H}_{2} \mathrm{O} / \mathrm{CH}_{3} \mathrm{OH}$ ratio on $\mathrm{CO}$ and hydrogen production at the reformer. The increase in the water content, increases the hydrogen production because methanol conversion is increased, but the most important impact is the decrease of $\mathrm{CO}$ content due to the water-gasshift reaction which favors the PROX operation.

TABLE I. SENSITIVITY OF THE SYSTEM IN THE $\mathrm{H}_{2} \mathrm{O} / \mathrm{CH}_{3} \mathrm{OH}$ RATIO

\begin{tabular}{|l|l|l|}
\hline \multicolumn{1}{|c|}{$\mathbf{H}_{2} \mathbf{O} / \mathbf{C H}_{3} \mathbf{O H}$} & \multicolumn{1}{|c|}{$\mathbf{C O}, \mathbf{p p m}$} & $\mathbf{H}_{\mathbf{2}}, \mathbf{~ m o l} / \mathbf{s e c}$ \\
\hline 1 & 9500 & 0.0537 \\
\hline 1.5 & 3010 & 0.0550 \\
\hline 2.0 & 1240 & 0.0558 \\
\hline
\end{tabular}

Similarly, table II presents the effect of the $\mathrm{O}_{2} / \mathrm{CH}_{3} \mathrm{OH}$ ratio on $\mathrm{CO}$ and hydrogen production and also to the peak temperature in the reformer. As can be seen, the increase of the $\mathrm{O}_{2} / \mathrm{CH}_{3} \mathrm{OH}$ ratio, causes an increase in hydrogen production since methanol conversion increases (reaches $\sim 100 \%$ ). Nevertheless, increased oxygen content causes an increase in the temperature levels that favor the $\mathrm{CO}$ production.

\section{TABLE II. SENSITIVITY OF THE SYSTEM IN THE $\mathrm{O}_{2} / \mathrm{CH}_{2} \mathrm{OH}$ RATIO}

\begin{tabular}{|l|l|l|l|}
\hline $\mathbf{O}_{2} / \mathbf{C H}_{\mathbf{3}} \mathbf{O H}$ & \multicolumn{1}{|c|}{$\mathbf{C O}, \mathbf{p p m}$} & $\mathbf{H}_{\mathbf{2}}, \mathbf{m o l} / \mathbf{s e c}$ & $\mathbf{T}_{\text {peak }}{ }^{\mathbf{0}} \mathbf{C}$ \\
\hline 0.1 & 1362 & 0.05478 & 300 \\
\hline 0.15 & 4067 & 0.056 & 310 \\
\hline 0.2 & 5905 & 0.056 & 338 \\
\hline
\end{tabular}

As it is obvious the selection of $\mathrm{H}_{2} \mathrm{O} / \mathrm{CH}_{3} \mathrm{OH}: 1.5$ and $\mathrm{O}_{2} / \mathrm{CH}_{3} \mathrm{OH}: 0.14$ is considered satisfactory as the hydrogen production remains at high levels and $\mathrm{CO}$ at low ones, which makes easier the minimization of $\mathrm{CO}$ at the PROX reactor. 
Moreover, high temperatures are excluded with the use of a lower $\mathrm{O}_{2} / \mathrm{CH}_{3} \mathrm{OH}$ ratio.

\section{ANALYSIS ON THE HEAT MANAGEMENT SYSTEM OF THE INTEGRATED POWER SYSTEM}

As described in Fig.1, heat management is required in various positions of the integrated system. The outlet of the two reactors needs to be cooled down before proceeding to the next subsystems, but the most challenging part in the modeling of the heat management system is the burner. In the burner, the fuel cell anode-off gas (contains unreacted hydrogen and a mixture of $\mathrm{CO}_{2}, \mathrm{~N}_{2}, \mathrm{CH}_{3} \mathrm{OH}$ and traces of $\mathrm{CO}$ ) enters the burner and provides heat to be used in the inlet reactants. However, as was found from Aspen Plus ${ }^{\circledR}$ simulations, the produced heat is lower than system heat requirements and additional methanol is needed to meet the demands. The additional methanol will be higher at the startup of the system (no anode-off gas will be present), but gradually the additional methanol will be decreased. Hence, the mathematical model needs to be accurate enough to be used in future control studies. Model predictive control is a suitable control scheme to be applied in such a power system, since the integrated unit will be studied under the developed mathematical model. The required power profile will be given as input and methanol flowrate will be manipulated to produce the hydrogen needed to serve the load demand. In the meantime, $\mathrm{CO}$ and temperature levels will be restricted in bounds in order to protect the various subsystems from deterioration (mainly PROX and fuel cell). All these consequent changes will be decided based on the minimization of an objective function that will take into account all the system necessary constraints.

\section{CONCLUSIONS}

An integrated power system for the production of hydrogen via autothermal reforming of methanol has been studied in this paper. The developed mathematical model for the two reactors and the PEM fuel cell was well found to simulate the dynamic operation of the unit where all the subsystems are connected to each other. The next step will be the integration of the heat management system (burner and heat exchangers) where the developed control scheme will try to maintain the variables of concern at their desired values (set points).

\section{Nomenclature}

$\begin{array}{ll}\mathrm{A}: & \text { heat transfer area, } \mathrm{m}^{2} \\ \mathrm{C}_{\mathrm{i}}: & \text { concentration of the component } \mathrm{i}, \mathrm{mol} / \mathrm{m}^{3} \\ \mathrm{Cp}_{\mathrm{c}}: & \text { coolant specific heat capacity, } \mathrm{J} / \mathrm{K} \mathrm{Kg} \\ \mathrm{C}_{\mathrm{p}}: & \text { specific heat capacity of the component } \mathrm{i}, \mathrm{J} / \mathrm{K} \mathrm{kg} \\ \mathrm{C}_{\mathrm{t}}: & \text { heat capacity of fuel cell, } \mathrm{J} /{ }^{\circ} \mathrm{C} \\ \mathrm{D}_{\mathrm{r}}: & \text { radial effective diffusivity, } \mathrm{m}^{2} / \mathrm{s} \\ \mathrm{D}_{\mathrm{z}}: & \text { axial effective diffusivity, } \mathrm{m}^{2} / \mathrm{s} \\ \mathrm{E}: & \text { thermodynamic cell voltage, } \mathrm{Volt} \\ \mathrm{F}: & \text { Faraday constant, } \mathrm{Cb} / \mathrm{mol} \\ \mathrm{F}_{\mathrm{c}}: & \text { coolant flowrate, } \mathrm{kg} / \mathrm{s} \\ \mathrm{F}_{\mathrm{i}}: & \text { flowrate of the component } \mathrm{i}, \mathrm{mol} / \mathrm{m}^{3} \\ \mathrm{~h}_{\mathrm{w}}: & \text { wall heat transfer coefficient, } \mathrm{W} / \mathrm{m}^{2} \mathrm{~K} \\ \mathrm{in}: & \text { inlet conditions } \\ \mathrm{i}: & \text { component that takes part at the system } \\ \mathrm{I}: & \text { operation current, A }\end{array}$

$\mathrm{j}: \quad$ reaction either in reformer or PROX

$\mathrm{k}_{\mathrm{r}}: \quad$ radial thermal conductivity, $\mathrm{J} / \mathrm{m}^{2} \mathrm{~s} \mathrm{~K}$

$\mathrm{k}_{\mathrm{z}}$ : $\quad$ axial thermal conductivity, $\mathrm{J} / \mathrm{m}^{2} \mathrm{~s} \mathrm{~K}$

$n_{c}: \quad$ number of cells of the PEM fuel cell

$\mathrm{n}_{\mathrm{e}}$ : number of electrons

$\mathrm{n}_{\mathrm{F}}: \quad$ Faraday efficiency, $\%$

$\mathrm{P}_{\mathrm{i}}$ : $\quad$ partial pressure of the component $\mathrm{i}$, bar

$\mathrm{P}_{\mathrm{fc}}$ : fuel cell power, Watt

$\mathrm{P}_{\text {reactor: }}$ reactor pressure, bar

Q: $\quad$ heat removed by the cooling jacket, $\mathrm{J} / \mathrm{s}$

$\mathrm{Q}_{\text {an/cat }}$ : anode/cathode flowrate, $\mathrm{m}^{3} / \mathrm{s}$

$\mathrm{Q}_{0}$ : $\quad$ volumetric flow, $\mathrm{m}^{3} / \mathrm{s}$

$\mathrm{r}: \quad$ radius of the reactor, $\mathrm{m}$

$\mathrm{R}_{\mathrm{j}}$ : $\quad$ kinetic expression of the reaction $\mathrm{j}, \mathrm{mol} / \mathrm{kg}_{\mathrm{cat}} \mathrm{s}$

$\mathrm{R}_{\mathrm{t}}$ : thermal resistance at the fuel cell, ${ }^{\circ} \mathrm{C} / \mathrm{W}$

S: $\quad$ cross section of the reactor, $\mathrm{m}^{2}$

t: $\quad$ time, $s$

$\mathrm{T}: \quad$ temperature, $\mathrm{K}$

$\mathrm{T}_{\mathrm{c}}$ : $\quad$ coolant temperature, $\mathrm{K}$

$\mathrm{T}_{\mathrm{fc}}$ : $\quad$ PEM fuel cell temperature, $\mathrm{K}$

$\mathrm{T}_{\text {amb }}$ : ambient temperature, $\mathrm{K}$

$\mathrm{u}$ : $\quad$ superficial gas velocity, $\mathrm{m} / \mathrm{s}$

U: overall heat transfer coefficient, $\mathrm{W} / \mathrm{m}^{2} \mathrm{~K}$

$\mathrm{V}_{\text {an } / \mathrm{cat}}: \quad$ anode/cathode volume, $\mathrm{m}^{3}$

$\mathrm{V}_{\mathrm{c}}: \quad$ coolant jacket volume, $\mathrm{m}^{3}$

$\mathrm{V}_{\mathrm{fc}}: \quad$ operation cell voltage, Volt

$\mathrm{z}: \quad$ length of the reactor, $\mathrm{m}$

$\Delta \mathrm{G}_{\mathrm{f}}$ : $\quad$ Gibbs free energy of formation, $\mathrm{J} / \mathrm{mol}$

$\Delta \mathrm{H}_{\mathrm{R}, \mathrm{T}, \mathrm{j}}: \quad$ enthalpy of reaction $\mathrm{j}$ at temperature $\mathrm{T}, \mathrm{J} / \mathrm{mol}$

$\varepsilon_{\text {cat }}: \quad$ void fraction of the catalyst

$v_{i, j}$ : coefficient of the component $i$ in the reaction $j$

$\rho_{\mathrm{i}}$ : $\quad$ density of the component $\mathrm{i}, \mathrm{kg} / \mathrm{m}^{3}$

$\rho_{\mathrm{c}}$ : $\quad$ coolant density, $\mathrm{kg} / \mathrm{m}^{3}$

\section{REFERENCES}

[1] D. Ipsakis, S. Voutetakis, P. Seferlis, F. Stergiopoulos, S Papadopoulou, and C. Elmasides, "The Effect of the Hysteresis Band on Power Management Strategies in a Stand-Alone Power System" Energy, vol. 33, 2008, pp. 1537-1550

[2] M. Ouzounidou, D. Ipsakis, S. Voutetakis, S. Papadopoulou, and P. Seferlis, "A combined methanol autothermal steam reforming and PEM fuel cell pilot plant unit: Experimental and simulation studies", (submitted in Energy, Special Issue for PRES08, 2008)

[3] B. Lindström and L.J. Petterson, "Hydrogen generation by steam reforming of methanol over copper-based catalysts for fuel cell applications", International Journal of Hydrogen Energy, vol. 26, 2001, pp. 923-933.

[4] F. Mariño, C. Descorme, and D. Duprez, "Noble metal catalysts for the preferential oxidation of carbon monoxide in the presence of hydrogen (PROX)", Applied Catalysis B: Environmental, Vol. 54, 2004, pp. 59-66

[5] J. C. Amphlett, K. A. M. Creber, J. M. Davis, R. F. Mann, B. A. Peppley and D. M. Stokes, "Hydrogen production by steam reforming of methanol for polymer electrolyte fuel cells" International Journal of Hydrogen Energy, vol. 19, 1994, pp. 131-137

[6] F. Cipitì, L. Pino, A. Vita, M. Laganà and V. Recupero, "Model-based investigation of a $\mathrm{CO}$ preferential oxidation reactor for polymer electrolyte fuel cell systems", International Journal of Hydrogen Energy, Vol. 32, 2007, pp. 4040-4051

[7] J. S. Suh, M. T. Lee, R. Greif and C.P. Grigoropoulos, "A study of steam methanol reforming in a microreactor", Journal of Power Sources, Vol. 173, 2007, pp. 458-466

[8] T. Stamps and E.P. Gatzke, "Dynamic modeling of a methanol reformer-PEMFC stack system for analysis and design" Journal of Power Sources, Vol. 161, 2006, pp. 356-370

[9] J. Larminie and A. Dicks, "Fuel Cell Systems Explained" 2nd Edition, John Wiley \& Sons Ltd, 2003

[10] S. H. Chan and H.M. Wang, "Thermodynamic and kinetic modelling of an autothermal methanol reformer", Journal of Power Sources, vol. 126,2004 , pp. $8-15$ 